\title{
P 306
}

\section{看護者の燃え尽きに関連する要因}

○久保田進也 ${ }^{11}$ 、清水隆司 ${ }^{21}$ 、三囟徳雄 ${ }^{11}$ 、永田頌史 ${ }^{11}$

(産業医科大学 精神保健学教室 ${ }^{1)}$ 産業医実務研修センター ${ }^{2}$ )

【目的】看護者の示すストレス反応には、さまざ まなものがあるが、その一つとして「燃え尽き」 がある。本研究では、看護者の燃えつき状態と、 個人特性さらに自尊感情、ソーシャルサポートと の関係を質問紙によって調査したので報告する。

【方法および対象】某総合病院に勤務する看護者 359 名を対象として、郵送法による自記式質問紙 調查を配布し、341 人から回答を得た（回収率 95\%)。質問紙は、性、年齢、職場（外来・手術・ 病棟勤務)、職制、経験年数、婚姻の有無を個人 特性とし、使用した尺度は Maslach Burnout Inventory （燃え尽き：MBI、「頻度」を使用） および、下位尺度「心身疲弊感」「個人的達成感」

「非人間化」、Rosenberg $の$ Self-Esteem (自尊感 情：SE）、およびNIOSH の Social Support（社 会的支援 : SS）を用いた。欠損值などを含む回答 は分析から除外し、最終的に解析の対象となった のは、280名である。対象者の性別は 99\%が女性 であったため男性は除外した。平均年齢は $29.5 \pm$ 7.3、経験年数は平均 $8.7 \pm 6.9$ で、職制は回答者 の 93\%がスタッフであり、主任クラスが 7\%であ った。婚姻状況の割合は、未婚 $84 \%$ 、既婚 $15 \%$ であった。解析では、経験年数は 25,75 パーセン タイル值を基淮に、経験年数が多い群・中間群・ 少ない群の 3 群に分けた。年代別では分布を考慮 し、24 歳以下 $\cdot 25 \sim 29$ 歳・ 30 39 歳・ 40 歳以 上の 4 群に分類した。

【結果】MBI では、未婚者群は既婚者群に比べて スコアが有意に高かった $(\mathrm{p}<0.01)$ 。職場による 検討では病棟勤務者のスコアが高い傾向が見ら れたが、職場間の差は認められなかった。経験年 数では、中間群は他の 2 群よりもスコアが有意に 高かった $(p<0.05)$ 。職制による差は認められず、 年代別による差も認められなかった。下位尺度で
は、全ての尺度で未婚者のスコアが有意に高かっ た。また、病棟勤務者は外来勤務者に比べて「心 身疲弊感」のスコアが有意に高かった $(p<0.05)$ が、 職場により婚姻状況が異なる可能性があるため 交互作用を検討したところ有意な差は認められ なかった。

SE に関しては、婚姻、職場、および職制によ る差はなかったが、年代別では 24 歳以下の年代 が 30 代および 40 代以上の年代よりも有意にスコ アが低かった $(\mathrm{p}<0.05)$ 。また経験年数が多い群は 少ない群に比べて、SE が有意に高かった $(\mathrm{p}<0.01)$ 。

SS に関しては、手術室勤務者は他の職場より も SS が高く、経験年数では年数が低い群は高い 群よりもSS が有意に高かった（ $\mathrm{p}<0.01 ） 。$ 職制、 婚姻状況による差はなかった。

尺度の相関を検討したところ、MBI、MBI 下位 尺度と SE および SS は有意な負の相関が認めら れた。

【まとめと考察】本看護集団のデータでは、未婚 者は既婚者よりも MBI のスコアが高い結果とな った。職場別では病棟勤務者は外来勤務者よりも

「心身疲弊感」は高く、婚姻と職場の交互作用も 認められないことから、病棟に勤務する未婚の看 護者の燃え尽きを検討する必要があると考えら れた。燃え尽きと自尊感情およびソーシャルサポ 一トは有意な負の相関が認められ、看護者の燃え 尽きと自尊感情との関連が示唆され、看護者の自 尊感情を高めていくことが燃え尽きを低下させ る可能性があると考えられた。

我々は、看護者のストレスマネジメントとして 「アサーティブ・トレーニング」を導入しており、 今後、個人のアサーティブの度合いと燃え尽きと の関連を検討していく予定である。 